\title{
From sandbox to "sandbox"
}

\author{
Manh-Toan Ho \\ Phenikaa University
}

14 October 2021

It is hard to remember how my neighborhood was when I was 10 . Only some vague memories continue to linger in my mind. There were large cây dâu da xoan (or Spondias lakonensis) that we used to climb, collect fruits or leaves. There was a large empty ground (we called it bãi cát, or sandbox) that we often went for soccer, and occasionally, bird trapping.

During that time, the neighborhood was a combination of dirt, sand, and asphalt. Big trees were still common, and kids could run around freely. Nowadays, asphalt roads have replaced the dirt roads, skyscrapers and housing complexes were erected in the large empty ground, and big trees have been cut down. The kids now sit safely inside their parents' cars, and once they go out, the parks offer an uninterrupted experience of artificial grass (see Figure 1).

\section{Figure 1. An example of the current model of children's playground in Vietnam}

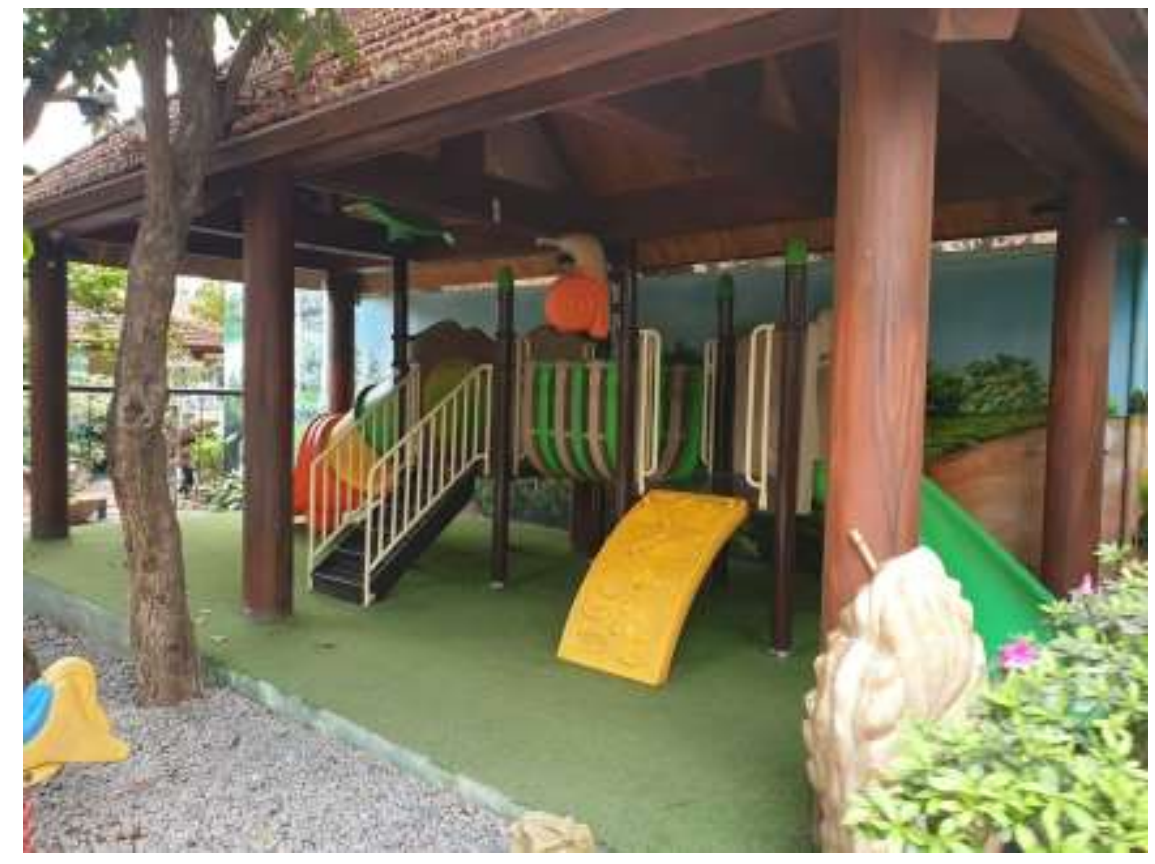

Figure 1 is a presentation of an illusion. The playground is inside a restaurant that, ironically, specializes in countryside animals. So, on one side of the restaurant is a lake where ducks can roam freely (until they are caught and turned into the hot pot dish). On this side, parents let their kids run and play. At least, the kids are safe from soil-related bacterial infections. 
Artificial grass is slowly becoming a norm for children's playgrounds, especially with the rise of apartment complexes. The type of playground that we know, the sandbox, is virtually extinct. Modern children have a different type of sandbox that allows them to play from their bedrooms: video games.

Figure 2 is a well-circulated image on the Internet. It is the celebration of technical achievement, of how far we have come from pixelated graphics in the 1950s. Modern technology has recreated reality to utmost perfection. Humans, or orges, or witches, inhabited these lands with their daily routines that are incredibly lifelike. The weather also interacts with you and other non-player characters (NPC) in a realistic manner: the cold makes you tremble, the rain makes you wet, and the thunder can hit your iron sword.

Figure 2. The scale of maps in video games

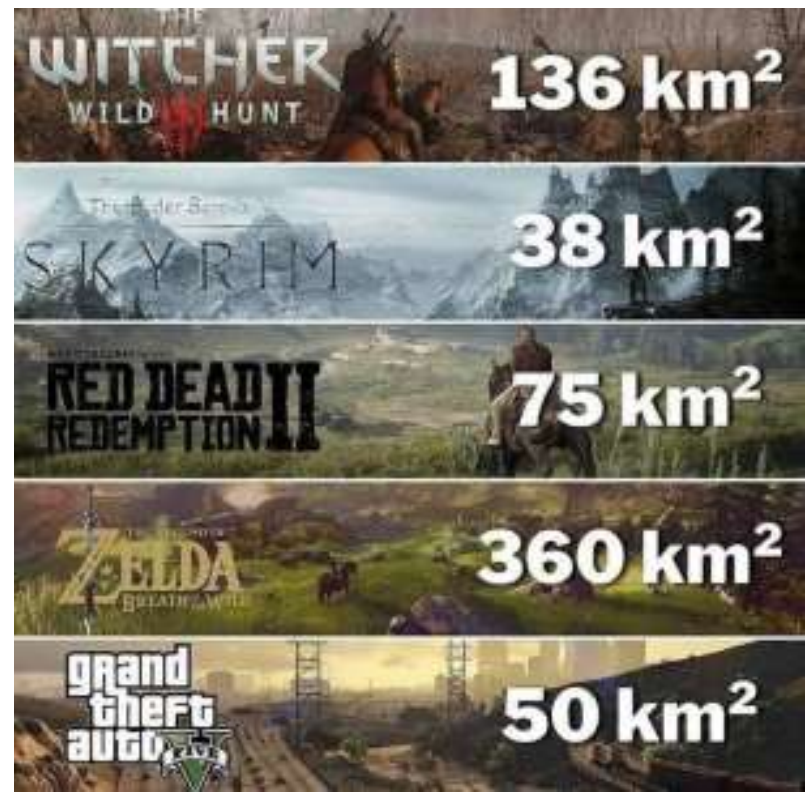

Last year, I started to spend a significant amount of time traversing the world of Breath of The Wild (which is $360 \mathrm{~km}^{2}$ ). Then, during the lockdown, the island in Animal Crossing: New Horizons provided me a comforting sanctuary with mundane tasks like fishing, planting trees, and flowers. That was when I thought about the connection between video games and our nature, or at least, our perception of nature. We began with simple self-reported questionnaires and surveyed more than 600 players [1]. The analysis suggested that when players are inside the virtual world, there is a high propensity toward environmentdestructive behaviors regardless of their actual perception. My initial assessment was that the game design offered no option for environmental protection. Around five months after my publication, Crowley, Silk, and Crowley (2021) used the world of Red Dead Redemption $2\left(75 \mathrm{~km}^{2}\right)$ to study the educational aspect of the game [2]. The researchers tested players and non-players' knowledge of the wildlife species that was depicted in the game. The interaction with the species inside the virtual world helped the players identify more species, especially ungulates and fishes.

I am glad that I have made a small contribution to our understanding of the connection between the environment and video games. Video game research is a young discipline, and too many efforts have been put into the debate of whether video games causing violent behaviors or not $[3,4]$. Amidst the inconclusive evidence from scientific research, the video game industry has become the dominant entertainment of 
the young generation. Thus, the question is no longer if video games are causing anything but if we can utilize video games for a good cause.

In reality, the relationship between the video game industry, and the digital industries at large, with the environment is not entirely clear-cut. At first, the concept of green was circulated in the video game industry as in how to use less plastic and to make more eco-friendly packaging $[5,6]$. However, when the digital stores open, the Internet becomes faster, and more gamers choose to download games rather than owning a hardcopy; the concept of being environment-friendly for the video game industry has slowly moved to carbon footprints and energy consumption. Indeed, tracing the cleanliness of the energy sources was not easy. Currently, we kind of know that something is not right, but to figure out precisely what is wrong and how bad it needs a cumulative effort from all sides: gamers, publishers, designers, policymakers, researchers, and so on [7].

The in-depth report by Chris Tapsell and Robert Purchese has provided a comprehensive overview of the issue and how we, as the consumer, strive for more responsible and sustainable game playing [7]. We need more like this, both from journalists and researchers. This is also what I will continue to focus on in the foreseeable future. Video games are my personal passion, and I have a lifelong legacy of works to build upon [8-11]. That would be quite a lot of materials for a rich research project. Focusing on a developing nation like Vietnam, where technological development and environmental protection must go hand in hand [12], it feels like a sandbox with many endless possibilities.

\section{References}

[1] Vuong, Q. H., et al. (2021). On the environment-destructive probabilistic trends: a perceptual and behavioral study on video game players. Technology in Society, 64, 101530.

[2] Crowley, E. J., Silk, M. J., \& Crowley, S. L. (2021). The educational value of virtual ecologies in Red Dead Redemption 2. People and Nature, DOI: 10.1002/pan3.10242

[3] Etchells, P. (2019). Lost in a Good Game: Why we play video games and what they can do for us. Icon Books.

[4] Johannes, N., Vuorre, M., \& Przybylski, A. K. (2021). Video game play is positively correlated with wellbeing. Royal Society Open Science, 8(2), 202049.

[5] Purchese, R. (2010). How green is the games industry?. Eurogamer. Retrieved from https://www.eurogamer.net/articles/how-green-is-the-games-industry

[6] Martin, S. (2020). The inescapable impact of plastics in the video game industry. Eurogamer. Retrieved from https://www.eurogamer.net/articles/2020-02-16-the-inescapable-impact-of-plastics-onthe-video-game-industry

[7] Tapsell, C., \& Purchese, R. (2021). What does gaming's all-digital future mean for the climate crisis?. Eurogamer. URL: https://www.eurogamer.net/articles/2021-10-13-gaming-downloads-climatecrisis

[8] Vuong, Q. H., Napier, N. K., Vu, H., Nguyen, M. C., \& Tran, T. D. (2014). Measuring corporate innovation capacity: experience and implications from i2Metrix implementation in Vietnam. ASEAN Journal of Management \& Information, 1(1), 1-17. 
[9] Vuong, Q. H. (2021). The semiconducting principle of monetary and environmental values exchange. Economics and Business Letters, 10(3), 1-9.

[10] Vuong, Q. H., Napier, N. K. (2015). Acculturation and global mindsponge: an emerging market perspective. International Journal of Intercultural Relations, 49, 354-367. DOI: 10.1016/j.ijintrel.2015.06.003.

[11] Vuong, Q. H. (2018). The (ir)rational consideration of the cost of science in transition economies. Nature Human Behaviour, 2(1), 5.

[12] Chính PM, \& Hoàng VQ. (2021). Kinh tế Việt Nam: Thăng trầm và đột phá. Nxb Chính trị Quốc gia Sự thật, Hà Nội. 